
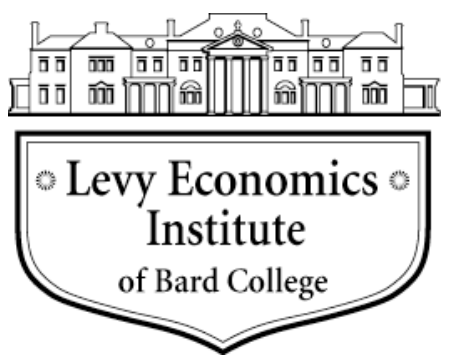

Working Paper No. 619

\title{
Asia and the Global Crisis: Recovery Prospects and the Future
}

by

\author{
Jesus Felipe*
}

September 2010

* Principal economist, Central and West Asia Department, Asian Development Bank, Manila, Philippines; email: jfelipe@adb.org. The article expresses the views of the author and not those of the Asian Development Bank, its executive directors, or the countries that they represent.

The Levy Economics Institute Working Paper Collection presents research in progress by Levy Institute scholars and conference participants. The purpose of the series is to disseminate ideas to and elicit comments from academics and professionals.

Levy Economics Institute of Bard College, founded in 1986, is a nonprofit, nonpartisan, independently funded research organization devoted to public service. Through scholarship and economic research it generates viable, effective public policy responses to important economic problems that profoundly affect the quality of life in the United States and abroad.

Levy Economics Institute P.O. Box 5000

Annandale-on-Hudson, NY 12504-5000

http://www.levyinstitute.org

Copyright (C) Levy Economics Institute 2010 All rights reserved 


\begin{abstract}
The global crisis of 2007-09 affected developing Asia largely through a decline in exports to the developed countries and a slowdown in remittances. This happened very quickly, and by 2009 there were already signs of recovery (except on the employment front). This recovery was led by China's impressive performance, aided by a large stimulus package and easy credit. But China needs to make efforts toward rebalancing its economy. Although private consumption has increased at a fast pace during the last decades, investment has done so at an even faster pace, with the consequence that the share of consumption in total output is very low. The risk is that the country may fall into an underconsumption crisis.

Looking at the medium and long term, developing Asia's future is mixed. There is one group of countries with a highly diversified export basket. These countries have an excellent opportunity to thrive if the right policies are implemented. However, there is another group of countries that relies heavily on natural resources. These countries face a serious challenge, since they must diversify.
\end{abstract}

Keywords: Asia; China; Global Crisis; Open Forest

JEL Classifications: E61; O11; O53, O57 


\section{INTRODUCTION}

In this paper I provide an analysis of how the crisis has affected Asia, the region's prospects of recovery, and the key factors that will determine its performance in the medium and long term.

The April 2009 issue of the IMF's World Economic Outlook noted that "the global economy is experiencing its deepest downturn in 50 years” (IMF 2009: 11). According to the Fund's estimates the world economy has experienced four troughs over the past 50 years-1975, 1982, 1991, and 2009. These correspond to declines in world real GDP per capita. Two features of the current recession suggest that it is likely to be unusually severe and that it will be followed by a weaker-than-average recovery (Reinhart and Rogoff 2009). First, it is associated with a deep financial crisis. Second, it appears to be highly synchronized across countries. However, in the September 2009 World Economic Outlook, the IMF announced that the recession was over and that in 2009 the world economy would contract by 1.1\%. This is the only year the world economy would experience a contraction since 1960. For 2010, the Fund predicts that global growth will reach 3.1\%. Much of this recovery is expected to be the result of developing Asia's expansion, led by China. The problem is that this expected recovery in output growth masks the fact that the crisis has led to a net loss of 20 million jobs and that over 40 million workers are at risk of dropping out of the labor force or of joining the ranks of the long-term unemployed (ILO 2009: 1). It is difficult to talk of recovery and end of the crisis in these circumstances.

The remainder of the paper is structured as follows. Section 2 discusses how growth forecasts for Asia have evolved. Section 3 discusses the region's recovery prospects and argues that developing Asia is not uncoupling from the rest of the world. Section 4 offers a discussion of China and the need to rebalance its economy, and of the challenges that it faces. Section 5 discusses developing Asia’s medium- and long-term growth prospects based on recent work on structural transformation. Finally, section 6 highlights two important questions that policymakers in Asia will have to pay attention to. The first one is the need to understand long-run growth as a process of structural transformation. The second one is that, despite high growth, unemployment and underemployment are pervasive in many countries across the region. Policymakers across 
developing Asia must implement policies that lead to the full employment of the labor force.

\section{EVOLVING GROWTH FORECASTS FOR DEVELOPING ASIA}

Until late 2008, many experts thought that this crisis would not hit developing Asia. The main reason was that the region had very limited direct exposure to the toxic assets that originated in Western financial institutions.

However, during the latter part of 2008, it was clear that the crisis was spreading quickly to Asia. The main channel was the real economy, mainly the collapse of exports and the fall in tourism receipts, as well as lower demand for immigrant labor services from the region. Private external capital flows into the region also slowed sharply.

The intensity with which different countries have been affected has depended on their integration into the global financial markets, their reliance on external demand, and their sensitivity to commodity price fluctuations. Overall, the more export-oriented Asian economies have suffered the most.

East and Southeast Asian economies have been badly affected. Japan’s economy contracted by $12 \%$ (annualized rate) in the fourth quarter of 2008. The GDP of the newly industrialized economies declined at rates between 10\% and 25\%. Southeast Asian countries have also been badly damaged. China and India have been affected through the contraction of their export sectors, but their economies have continued to grow because trade represents a smaller share of the economy, and because active measures have supported domestic activity.

The central Asian economies have also been affected in varying degrees, although overall they will experience the largest reversal of economic fortune over the near term. Linkages to international financial markets are weak in most of these countries. They are being affected through three channels: (i) falling commodity prices; (ii) declining export demand; and (iii) lower remittance inflows.

Table 1 summarizes the Asian Development Bank’s (ADB) annual growth rate forecasts for the region, taken from the Asian Development Outlook, published in April, and from the Asian Development Outlook Update, published in September. The two forecasts in each Outlook correspond to the year in question and the following year. The 
table indicates that even in September 2008, when it published the Update, while recognizing increasing uncertainty and acknowledging that Asia would be affected by the developments elsewhere, ADB was still upbeat about the region, as average growth for 2009 was forecast at 7.2\%, only marginally below the April forecast of 7.8\%. Taking into account that the developed world was already suffering the consequences of the crisis, the belief was still that the Asian economies would only be moderately affected by it. However, by April 2009, ADB had downgraded the overall forecast for the region to $3.4 \%$, but thought that the recession would be relatively short lived and that a quick recovery would set in with growth in 2010 reaching 6\%. Things did not change much in the September 2009 Update forecast, although ADB is slightly more optimistic: the region's 2009 growth is expected to reach 3.9\% in 2009, and the prospects for 2010 are marginally better than those six months earlier, with regional growth reaching $6.4 \%$.

Given the latest data, a growing number of economists agree, though with a high degree of caution, that this is the beginning of a $\mathrm{V}$-shaped recovery. 
Table 1. Asian Development Outlook (ADO) Growth Forecasts

\begin{tabular}{|c|c|c|c|c|c|c|c|c|c|c|c|c|}
\hline & \multicolumn{2}{|c|}{ ADO 2007 } & \multicolumn{2}{|c|}{$\begin{array}{l}\text { ADO 2007 } \\
\text { Update }\end{array}$} & \multicolumn{2}{|c|}{ ADO 2008} & \multicolumn{2}{|c|}{$\begin{array}{c}\text { ADO 2008 } \\
\text { Update }\end{array}$} & \multicolumn{2}{|c|}{ ADO 2009} & \multicolumn{2}{|c|}{$\begin{array}{c}\text { ADO 2009 } \\
\text { Update }\end{array}$} \\
\hline & 2007 & 2008 & 2007 & 2008 & 2008 & 2009 & 2008 & 2009 & 2009 & 2010 & 2009 & 2010 \\
\hline Central Asia & 10.3 & 9.4 & 11.1 & 10.1 & 7.5 & 8.4 & 7.6 & 8.0 & 3.9 & 4.8 & 0.5 & 3.6 \\
\hline Armenia & 10.0 & 9.0 & 11.0 & 9.0 & 10.0 & 8.0 & 10.0 & 8.0 & 0.5 & 3.0 & -9.9 & 0.9 \\
\hline Azerbaijan & 25.0 & 17.0 & 27.0 & 20.0 & 15.7 & 18.0 & 15.7 & 14.0 & 8.0 & 6.7 & 3.0 & 4.5 \\
\hline Georgia & - & - & - & - & 6.5 & 7.0 & - & - & 2.5 & 6.0 & -4.0 & 2.5 \\
\hline Kazakhstan & 8.6 & 8.9 & 9.0 & 8.9 & 5.0 & 6.3 & 5.0 & 6.3 & 2.0 & 3.3 & -1.0 & 2.5 \\
\hline Kyrgyz Republic & 4.0 & 5.0 & 6.0 & 7.0 & 7.6 & 7.6 & 7.0 & 6.5 & 4.0 & 6.0 & 1.0 & 2.0 \\
\hline Tajikistan & 7.5 & 7.1 & 7.5 & 8.0 & 8.0 & 8.0 & 5.0 & 7.0 & 3.0 & 4.0 & 0.5 & 2.0 \\
\hline Turkmenistan & 8.5 & 8.5 & 10.0 & 10.0 & 10.0 & 10.0 & 10.0 & 10.0 & 10.0 & 10.0 & 8.0 & 10.0 \\
\hline Uzbekistan & 7.4 & 7.1 & 8.0 & 7.5 & 7.8 & 7.2 & 8.0 & 8.0 & 7.0 & 6.5 & 7.0 & 6.5 \\
\hline East Asia & 8.0 & 8.0 & 8.9 & 8.7 & 8.1 & 8.2 & 8.0 & 7.7 & 3.6 & 6.5 & 4.4 & 7.1 \\
\hline China, People's Rep. of & 10.0 & 9.8 & 11.2 & 10.8 & 10.0 & 9.8 & 10.0 & 9.5 & 7.0 & 8.0 & 8.2 & 8.9 \\
\hline Hong Kong, China & 5.4 & 5.2 & 6.0 & 5.4 & 4.5 & 4.8 & 4.5 & 4.5 & -2.0 & 3.0 & -4.0 & 3.0 \\
\hline Korea, Rep. of & 4.5 & 4.8 & 4.6 & 5.0 & 5.0 & 5.2 & 4.6 & 4.5 & -3.0 & 4.0 & -2.0 & 4.0 \\
\hline Mongolia & 7.0 & 7.0 & 8.0 & 8.0 & 9.5 & 9.0 & 9.0 & 8.0 & 3.0 & 4.5 & 2.8 & 4.3 \\
\hline Taipei,China & 4.3 & 4.5 & 4.6 & 4.5 & 4.2 & 5.6 & 4.2 & 4.6 & -4.0 & 2.4 & -4.9 & 2.4 \\
\hline South Asia & 7.7 & 8.0 & 8.1 & 8.1 & 7.6 & 8.1 & 7.1 & 6.7 & 4.8 & 6.1 & 5.6 & 6.4 \\
\hline Afghanistan, Islamic Rep. of & 10.0 & 10.0 & 13.0 & 8.4 & 9.0 & 9.0 & 7.5 & 8.3 & 9.0 & 7.5 & 15.7 & 8.5 \\
\hline Bangladesh & 6.5 & 7.0 & 6.5 & 6.5 & 6.0 & 6.5 & 6.2 & 6.5 & 5.6 & 5.2 & 5.9 & 5.2 \\
\hline Bhutan & 18.0 & 10.0 & 18.0 & 10.0 & 14.4 & 7.2 & 14.4 & 7.2 & 5.5 & 6.5 & 6.0 & 6.5 \\
\hline India & 8.0 & 8.3 & 8.5 & 8.5 & 8.0 & 8.5 & 7.4 & 7.0 & 5.0 & 6.5 & 6.0 & 7.0 \\
\hline Maldives & 12.1 & 8.0 & 7.3 & 8.0 & 8.0 & 7.0 & 6.5 & 7.0 & 1.0 & 1.5 & -3.5 & 3.5 \\
\hline Nepal & 2.8 & 2.8 & 2.5 & 2.8 & 3.8 & 4.3 & 5.6 & 5.0 & 3.0 & 3.5 & 3.8 & 4.0 \\
\hline Pakistan & 6.8 & 6.5 & 7.0 & 6.5 & 6.3 & 6.5 & 5.8 & 4.5 & 2.8 & 4.0 & 2.0 & 3.0 \\
\hline Sri Lanka & 6.1 & 6.0 & 6.1 & 6.0 & 6.0 & 6.0 & 6.0 & 6.0 & 4.5 & 6.0 & 4.0 & 6.0 \\
\hline Southeast Asia & 5.6 & 5.9 & 6.1 & 6.1 & 5.7 & 6.0 & 5.4 & 5.4 & 0.7 & 4.2 & 0.1 & 4.3 \\
\hline Brunei Darussalam & - & - & - & - & - & - & - & - & -0.4 & 2.3 & -1.2 & 2.3 \\
\hline Cambodia & 9.5 & 9.0 & 9.2 & 8.0 & 7.5 & 7.0 & 6.5 & 6.0 & 2.5 & 4.0 & -1.5 & 3.5 \\
\hline Indonesia & 6.0 & 6.3 & 6.2 & 6.4 & 6.0 & 6.2 & 6.2 & 6.2 & 3.6 & 5.0 & 4.3 & 5.4 \\
\hline Lao People's Dem. Rep. & 6.8 & 6.5 & 6.8 & 6.5 & 7.7 & 7.8 & 7.5 & 7.6 & 5.5 & 5.7 & 5.5 & 5.7 \\
\hline Malaysia & 5.4 & 5.7 & 5.6 & 5.7 & 5.4 & 5.9 & 5.6 & 5.3 & -0.2 & 4.4 & -3.1 & 4.2 \\
\hline Myanmar & - & - & - & - & - & - & - & - & - & - & - & - \\
\hline Philippines & 5.4 & 5.7 & 6.6 & 6.0 & 6.0 & 6.2 & 4.5 & 4.7 & 2.5 & 3.5 & 1.6 & 3.3 \\
\hline Singapore & 6.0 & 5.5 & 7.5 & 6.0 & 5.2 & 5.8 & 4.2 & 4.6 & -5.0 & 3.5 & -5.0 & 3.5 \\
\hline Thailand & 4.0 & 5.0 & 4.0 & 5.0 & 5.0 & 5.2 & 5.0 & 5.0 & -2.0 & 3.0 & -3.2 & 3.0 \\
\hline Vietnam & 8.3 & 8.5 & 8.3 & 8.5 & 7.0 & 8.1 & 6.5 & 6.0 & 4.5 & 6.5 & 4.7 & 6.5 \\
\hline The Pacific & 4.5 & 2.8 & 3.5 & 3.2 & 4.4 & 3.3 & 4.8 & 3.4 & 3.0 & 2.7 & 2.8 & 3.1 \\
\hline Cook Islands & 3.2 & 3.9 & 2.5 & 3.5 & 3.5 & 3.5 & 2.5 & 2.9 & 1.0 & 0.8 & $\begin{array}{l}-0.1 \\
\end{array}$ & 0.8 \\
\hline Fiji Islands & -2.3 & 1.3 & -3.1 & 1.5 & 1.6 & 1.6 & 1.7 & 1.4 & -0.5 & 0.2 & -1.0 & 0.5 \\
\hline Kiribati & - & - & 1.0 & 1.0 & 1.0 & 1.0 & 0.6 & 0.8 & 1.0 & 0.9 & 1.0 & 0.9 \\
\hline Marshall Islands, Rep. of & 3.5 & - & 2.5 & - & 1.0 & 1.0 & -4.2 & -2.2 & 0.5 & 0.8 & 0.5 & 0.8 \\
\hline Micronesia. Fed. States of & 1.0 & 1.5 & 1.0 & 1.5 & -3.5 & -3.0 & -5.0 & -2.2 & -0.1 & 0.8 & 0.5 & 0.5 \\
\hline Nauru & - & - & - & - & -2.4 & -4.4 & -2.4 & 1.5 & 1.5 & 1.5 & 1.0 & 0.0 \\
\hline Palau, Rep. of & 5.5 & 4.8 & 5.5 & 4.8 & 2.0 & 3.0 & 1.2 & 2.2 & -2.0 & -0.2 & -3.0 & -1.0 \\
\hline Papua New Guinea & 4.5 & 3.5 & 5.2 & 4.5 & 6.6 & 4.6 & 7.6 & 5.1 & 4.0 & 3.5 & 4.5 & 3.9 \\
\hline Samoa & 3.1 & 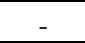 & 3.1 & - & 3.0 & 3.0 & 3.3 & 2.5 & -1.0 & -0.1 & -0.8 & -0.6 \\
\hline Solomon Islands & 5.0 & 4.0 & 6.3 & 4.0 & 6.0 & 2.5 & 8.0 & 4.0 & 2.2 & 1.7 & 0.0 & 2.6 \\
\hline Timor-Leste, Dem. Rep. of & 32.1 & 3.5 & 22.0 & 3.5 & 6.5 & 4.9 & 6.5 & 4.9 & 10.0 & 8.0 & 8.0 & 9.0 \\
\hline Tonga & 0.0 & 2.9 & -3.5 & 0.1 & 1.0 & 2.0 & 1.0 & 2.0 & -2.0 & -0.6 & -0.5 & 0.5 \\
\hline Tuvalu & 2.5 & 2.5 & 2.5 & 2.5 & 2.0 & 2.0 & 1.2 & 1.6 & 1.0 & 0.9 & 1.0 & 1.0 \\
\hline Vanuatu & 4.7 & 4.6 & 4.7 & 4.6 & 5.7 & 4.3 & 5.7 & 2.9 & 3.5 & 0.8 & 4.0 & 3.5 \\
\hline Average & 7.6 & 7.7 & 8.3 & 8.2 & 7.6 & 7.8 & 7.5 & 7.2 & 3.4 & 6.0 & 3.9 & 6.4 \\
\hline
\end{tabular}

Source: Asian Development Outlook 2007, 2008, and 2009 (published in April). Asian Development Outlook Update 2007, 2008, and 2009 (published in September). 
What happened during the last months of 2008 and the early months of 2009? By then it had become clear that Asia would not be spared from the crisis, that it had not decoupled from the developed world, and that the region would see a decline in export growth that would lead to a significant deceleration in overall growth. It also became clear that growth in all subregions would falter. The central Asian economies and the Pacific Islands would be severely affected. Growth in Southeast Asia was expected to collapse-just above zero, a view that has not changed in the September 2009 Update. Only the fiscal stimulus on domestic demand and a slight recovery in external demand will keep these economies afloat.

The south Asian growth average came down as a result of India's deteriorating prospects, with forecast growth at 5\% (revised up to 6\% in the September 2009 Update). India's recently announced budget provides an important boost to public expenditures.

In the case of east Asia, China’s growth forecast for 2009 significantly declined from 9.5\% in September of 2008 to 7\% in April of 2009, although it improved to 8.2\% in the September 2009 Update. China’s massive two-year fiscal stimulus package of about \$585 billion, announced in November 2008, and substantial loan growth (only 30\% of China's stimulus will come from the central government; most of the rest will be financed by the country’s banks) have played a key role in sustaining growth in $2009 .{ }^{1}$ China needed to implement this mammoth package to ensure that growth did not collapse and fall below the $8 \%$ that is estimated to be needed to generate employment and to ensure social stability. However, the package is failing on the second objective, as I argue in the last section. Finally, in early 2009 it became clear that the very open and exportoriented economies of Singapore, Taiwan, Korea, and Hong Kong would be badly hit, all of them registering significantly negative growth rates. This prognosis remains in the September 2009 Update.

\section{RECOVERY PROSPECTS: IS THE GLASS HALF FULL OR HALF EMPTY?}

Recent research by Gupta and Miniane (2009) on crises in east and Southeast Asia shows that recoveries have tended to be weak, because they have been, in general, driven by a single engine-exports_-and because have been investment-less. Other emerging

\footnotetext{
${ }^{1}$ Recent data on China seem to indicate that the effect of the fiscal stimulus is fading, and that the stimulus is coming not from the budget but from infrastructure projects run outside the budget.
} 
economies have managed to recover from crises faster due to a stronger contribution from domestic demand, in particular investment. Also, deep recessions in Asia have resulted in substantial declines in potential output growth, indicating that their effects are permanent. This may be because investment tends to decline during recessions. Comparing the period 2000-2006 with 1990-1996, growth slipped by an average 2.5\% a year in the five countries that were most directly affected by the 1997-1998 crisisIndonesia, Korea, Malaysia, Philippines, and Thailand. Likewise, these countries suffered a decline in participation rates among working-age men and have never recovered and reached precrisis levels.

The question that arises is: how will Asia manage to get out of the crisis this time, given that demand in the United States and Europe will not recover any time soon? It seems that the only way out will be a rebalancing toward domestic demand. This, however, will be very difficult in the short to medium term.

Many Asian countries have implemented stimulus packages (see table 2). However, it is virtually impossible to know the true amount of these packages. The Asian Development Outlook Update (2009: 27) indicates that "fiscal stimuli in 11 Asian developing economies averages 7.1\% of nominal 2008 GDP.” However, figures were calculated as the ratio of the amounts announced divided by 2008 GDP. In some countries, budgetary categories were simply reallocated, in other cases, taxes have been cut, while in others subsidies have increased. Finally, in some other cases, stimulus packages have taken the form of (additional) increases in government spending. 
Table 2. Stimulus Plans across Developing Asia

\begin{tabular}{|c|c|c|c|c|}
\hline China & Singapore & India & Indonesia & Georgia \\
\hline $\begin{array}{l}\text { Announced in } \\
\text { November 2008, } \\
\text { a two-year } \\
\text { stimulus package } \\
\text { worth CNY4 } \\
\text { trillion. Fiscal } \\
\text { deficit will } \\
\text { increase from } \\
0.4 \% \text { of GDP in } \\
2008 \text { to 3\% in } \\
2009 \text {. Almost } \\
90 \% \text { of China' s } \\
\text { plan is dedicated } \\
\text { to rural and } \\
\text { urban } \\
\text { infrastructure, } \\
\text { including } \\
\text { housing, post- } \\
\text { earthquake } \\
\text { reconstruction, } \\
\text { and water and } \\
\text { sanitation } \\
\text { facilities. } \\
\text { Improvements in } \\
\text { rural } \\
\text { transportation are } \\
\text { expected to lead } \\
\text { to new jobs close } \\
\text { to home. }\end{array}$ & $\begin{array}{l}\text { In January 2009, } \\
\text { the government } \\
\text { announced that it } \\
\text { would spend } \\
\text { S\$20.5 billion } \\
\text { (8\% of GDP). } \\
\text { Aside from } \\
\text { creating job } \\
\text { opportunities } \\
\text { through } \\
\text { infrastructure } \\
\text { projects, } \\
\text { Singapore is } \\
\text { offering } \\
\text { incentives for } \\
\text { companies to } \\
\text { keep their } \\
\text { employees, such } \\
\text { as subsidies for } \\
\text { salaries for } \\
\text { workers who } \\
\text { take part in } \\
\text { retraining } \\
\text { programs. Loans } \\
\text { will be more } \\
\text { available to } \\
\text { small- and } \\
\text { medium-sized } \\
\text { businesses, } \\
\text { which employ } \\
\text { the majority of } \\
\text { the workforce. }\end{array}$ & $\begin{array}{l}\text { Combined fiscal } \\
\text { deficit of } 10.8 \% \\
\text { of GDP for } \\
\text { FY2009. } \\
\text { India aims to } \\
\text { bolster labor- } \\
\text { intensive } \\
\text { industries and to } \\
\text { create jobs } \\
\text { through } \\
\text { infrastructure } \\
\text { projects. The } \\
\text { government is } \\
\text { also considering } \\
\text { the expansion of } \\
\text { its rural public } \\
\text { works program, } \\
\text { which will } \\
\text { guarantee } \\
\text { workers a 100- } \\
\text { day contract each } \\
\text { year. }\end{array}$ & $\begin{array}{l}\text { Stimulus } \\
\text { package of } \\
\text { Rp73.3 trillion of } \\
\text { tax incentives, } \\
\text { pay increases, } \\
\text { export } \\
\text { guarantees, cash } \\
\text { transfers, and } \\
\text { increased } \\
\text { government } \\
\text { spending. } \\
\text { Programs will be } \\
\text { expanded that } \\
\text { encourage laid- } \\
\text { off workers to } \\
\text { move to areas } \\
\text { where there are } \\
\text { many jobs. } \\
\text { Indonesia's plan } \\
\text { also relies } \\
\text { heavily on } \\
\text { infrastructure } \\
\text { and rural } \\
\text { development } \\
\text { programs. }\end{array}$ & $\begin{array}{l}\text { In addition to } \\
\text { infrastructure } \\
\text { projects, the } \\
\text { government } \\
\text { moved to protect } \\
\text { thousands of jobs } \\
\text { at the threatened } \\
\text { Russian-backed } \\
\text { manufacturer } \\
\text { Energy-invest by } \\
\text { making a large } \\
\text { purchase from } \\
\text { the company. }\end{array}$ \\
\hline
\end{tabular}

Source: Braningin (2009)

The IMF is more sanguine now than in mid-2009, and thinks that Asia will lead the recovery. Likewise, the 2009 Asian Development Outlook Update forecasts offer a more optimistic view of the region. However, it is worth noting that much of the improvement in developing Asia is due to China's weight in the region.

The possibility that the economies of developing Asia will shift to a domestic demand-led growth model is linked to the notion that the region is uncoupling from events in the rest of the world. What is the empirical evidence? An analysis by Asian Development Outlook (2007) indicates that although intraregional trade is increasing, in a globalizing world links among economies are becoming an even more powerful driver. Hence, the idea of developing Asia's uncoupling is more myth than reality. The truth is 
that the rise in intra-Asian economic interdependence through investment and trade is being driven by globalization. Much intra-Asian trade is conducted by multinational corporations and their affiliates in the form of intra-firm and intra-industry trade that involves fragmentation of production. More than 70\% of intra-Asian trade consists of intermediate goods used in production; of this, half is driven by final demand outside Asia. Nearly $80 \%$ of all exports from east and Southeast Asia are eventually bound for external markets. Of the total, about $60 \%$ is eventually consumed in the United States, the European Union (EU), and Japan. These three areas are still the main markets for east and Southeast Asia's exports after taking into account the share of the intermediate goods trade that is assembled and produced within the region but that is eventually shipped outside the region. Park and Shin (2009) conclude that although China is becoming more a consumer of final goods, it is still premature to see it acting as an independent regional engine. Its role of assembler still dominates, with final demand coming from the developed countries. Intra-regional trade in parts and components with China at the center is beneficial for developing Asia, but it also means that China does not have the capacity to become a growth engine for the region.

Therefore, it remains to be seen whether developing Asia will be capable of pulling the rest of the world or not. If China's recent high growth figures are interpreted with optimism in other countries and animal spirits return, then 2010 could witness a generalized and significant pick up in growth. Chinese authorities have indicated that loan growth will slow only gradually in 2010, to a targeted rate of about 20\% (compared to $30 \%$ in 2009); stimulus spending will continue further boosting construction. If economic agents in the rest of the world do not react positively-for example because they may fear that China’s high lending will lead to asset-price inflation (also fueled by low inflation and strong growth), unproductive investment, and excess capacity-then perhaps it will be too soon to claim victory. If it is true that the worst of the crisis is over, the Chinese authorities will then face the task of deciding when to relax on statesponsored stimulus programs. As noted above, China's growth is largely the result of massive credit expansion. The decision of how and when to ease back will be difficult, for if the stimulus is not withdrawn in a timely way, the desire not to stifle the recovery will risk overheating in asset markets. And it must not be forgotten that recovery of the world economy will depend on whether the financial crisis is truly over or not, as it is not 
well-known how the U.S. financial system has dealt with the subprime loans and the amount of them still in the system.

The key question is what type of recovery will take place (whenever it occurs). As I noted above, growth rates in the countries affected by the 1997-1998 financial crisis are significantly below precrisis rates, and unemployment has increased. I think that this crisis will see a reduction in potential output and employment rates, and that these trends will put downward pressure on wage rates, aggravating the risk of depressed consumption. I also foresee an increase in informality, typical of developing countries.

The October 2009 issue of the World Economic Outlook noted that often output does not recover to its precrisis trend and that the medium-term output losses following banking crises are significant: "Seven years after the crisis, output has declined relative to trend by close to $10 \%$ on average” (p. 125). Given the severity of this crisis, I have doubts that things will get back to normal soon (i.e., that there will be a strong recovery and, in particular, that employment will grow fast). The job crisis is far from over and the prospects of greater long-term joblessness can undermine confidence, thereby affecting consumption and investment decisions. In my view, economic recovery will remain both fragile and incomplete as long as the jobs crisis continues. For this reason, a premature exit from stimulus measures would be counterproductive and expensive in the long run.

\section{CHINA AND THE NEED TO REBALANCE THE ECONOMY (OR, THE NEED TO AVOID A CRISIS?)}

For years, discussions about global imbalances have focused on Asia's need to rebalance its sources of growth from export-led to domestic demand-led (private consumption) and, consequently, on the need to spend more and save less. Given space constraints, I will only make a few remarks on the issue. My view is that the need to rebalance the world economy, as played by some, obeys more to political considerations than to economics.

First of all, this policy recommendation suffers from a fallacy of composition. It appears as if all Asian countries were running immense current account surpluses, and private consumption as a share of total income was excessively low. This is not true. Average private consumption as a share of GDP in the region is 55-60\%, marginally below that of the OECD countries; it represents $70-80 \%$ of GDP in countries like 
Bangladesh, Cambodia, Philippines, Sri Lanka, or Pakistan. There is one country, however, where the share of private consumption in GDP is relatively low, well below 40\% (and where it has declined by about 15 percentage points since 1990)—China. ${ }^{2}$ This means that discussions have to concentrate on this country and not on the region as a whole. Second, China's problem is not that of a low and stagnant level of private consumption. Since 1980, consumption in China has grown at a staggering 15\% per annum, and the country has been immersed in a consumer boom for years (car sales, travel, consumer goods, housing). The problem is that investment has grown at an even faster pace, at about 25\% per annum between 2002 and 2008. This means that when analyzed in terms of shares in GDP, the share of private consumption has declined while that of investment has increased.

What could be the implications of a declining share of private consumption? The only way for China to achieve growth rates above $10 \%$ per annum for decades and to industrialize has been through very high rates of capital accumulation (Felipe et al. 2008). This rate can be written as follows: $\hat{K} \equiv \frac{I}{Y} \times \frac{Y}{K}$, where $\hat{K}$ is the growth rate of capital accumulation, $\frac{I}{Y}$ is the share of investment in GDP, and $\frac{Y}{K}$ is capital productivity (the inverse of the capital-output ratio). China's very high rates of capital accumulation were the result of increasingly high investment shares (reaching over 40\% of GDP), accompanied by a decline in capital productivity.

What is the main source of China's high investment-to-output ratio? The main source is reinvested corporate profits, as a large share of these earnings were not paid as dividends and stayed within the companies. In 2007, these amounted to about 22\% of GDP. The mirror image of the private consumption-investment dynamic is provided by the shares of wages and profits in GDP (which add up to unity by construction). The share of wages in China's national accounts has declined from almost $55 \%$ in the early 1990s to about 36\% recently (with the consequent increase in the share of profits). This situation poses a conundrum: how can labor, as a class, accept a permanent decline in its share of the country's total output? The answer is that it is possible provided certain conditions are met. China's spectacular boom is driven by massive productivity gains and

\footnotetext{
${ }^{2}$ The other two countries where the share of consumption is slightly below $50 \%$ are Malaysia and Singapore.
} 
increasing profits in manufacturing. As noted above, a large share of these profits is reinvested, which generates further manufacturing capacity (Felipe et al. 2008). It has been estimated that annual productivity growth in China's manufacturing sector grew at an average 20.4\% per annum between 1995 and 2003. This allowed substantial growth in real income that translated into large wage rate increases, of about $15 \%$ per annum. This explains the decline in the labor share in total income. As a class, Chinese labor may be willing to accept this as long as wage rates continue increasing significantly.

In the long run, however, and as the country develops, it will be very difficult to maintain these dynamics. As the size of the service sector increases, China will not be able to achieve growth rates of $10 \%$ per annum. As this takes place, the economy will rebalance, since the economy's growth rate over the long run will be determined to a large extent by the growth of productivity in the service sector, the least dynamic sector of the economy (Baumol, Blackman, and Wolff 1989).

We can now return to China's declining consumption share and analyze its implications. Aggregate consumption can be characterized as an income share weighted consumption function: $C=a+m p c_{L}\left(s^{L} Y\right)+m p c_{K}\left(s^{K} Y\right)$, where $C$ is consumption, $m p c_{L}$ and $m p c_{K}$ are the marginal propensities to consume of labor and capital, respectively (i.e., workers spend $m p c_{L}$ percent of their additional income on consumption and capitalists spend $m p c_{K}$ percent of their additional income on consumption, respectively; in the case of China, I have estimated $\left.m p c_{L}=0.50>m p c_{K}=0.37\right), P$ denotes total profit income (and $s^{K}=(P / Y)$ is the capital share in income), $W$ denotes total labor income (and $s^{L}=(W / Y)$ is the labor share in income), and $P+W=Y$, where $Y$ is the country's GDP. As the share of total income that goes to the owners of capital increases, workers have a lower income share because workers spend more and capitalists less on the margin, the overall marginal propensity of the economy (an income share weighted of the average of the two marginal propensities) to consume declines, implying that total consumption declines. This situation may lead to an underconsumption crisis, namely, a situation such that production is profitable, but the profits embedded in output cannot be realized due to deficient demand. This might eventually lead to reductions in capacity utilization, profit rates, investment, income, production, and, finally, in employment. Chinese policymakers should be aware of this chain of events, as China's key problem 
for the next decades will be employment generation, the key to the country's political stability.

In my view, the key challenge for China's policymakers during the next decade is to maintain a growth model whose ultimate outcome is employment generation and to avoid an underconsumption crisis. It is in this sense that China needs to rebalance its economy. Economic reforms should have this as background. Increases in spending in social infrastructure, such as education, healthcare, and the environment, as well as the gradual opening of markets to increase price competition or the development of the credit card market will be important in this rebalancing. If high investment continues being China's chosen strategy, then a decrease in indirect taxation of essential goods is advisable and an increase in taxation of nonessential goods, so that given the differential in marginal propensities, overall consumption tilts toward essentials. Finally, it is important to make sure that real wages of low-paid workers (who consume essential goods) increase. This is a challenge because investment-driven employment will probably induce inflationary pressures as the supply of necessities is limited. The increase in employment will increase the overall wage bill in nominal terms, but not in real terms (as prices have increased), and most likely real wages will decline.

China is still a relatively poor economy and, in the medium to long term, exports will have to continue playing a key role in its development. The reason is that the objective of the export-led growth strategy is not just to gear the economy toward exports. Rather, it is a development strategy based on upgrading and diversifying the economy. As Felipe et al. (2010) document, the reason China has done very well in the last decades is its capacity to upgrade and diversify its export basket.

Moreover, a major shift from export-led growth into domestic demand-led growth will require the development of different sectors of the economy, which requires a significant shift in resources, the transformation of the productive structure, and internal changes and reforms.

As a mater of principle, policies that lead to a gradual shift to domestic demandled growth should be welcome, especially in the context of the current crisis. The stimulus packages can play an important role if they focus on investment in infrastructure development (but not in sectors already burdened with too much capacity) and on labor- 
intensive sectors. ${ }^{3}$ Moreover, export-led growth and domestic demand-led growth need not be incompatible development strategies for China (as well as for many other countries in the region). In the end, the magic recipe is about achieving a golden combination between export-led growth and domestic demand-led growth. As Rodrik (2009) has argued, what matters for growth is the expansion of industrial activities (manufacturing in particular), and these can increase without increasing trade, if domestic demand also increases.

Finally, the question of whether China's exchange rate is undervalued or not, and whether its exchange rate policy gives it some advantage, has been debated for quite some time. Some argue that a stronger yuan would help rebalance China's economy, making it less dependent on exports. However, China rejects the accusation that its exchange rate policy gives it an unfair advantage. The Chinese argue that during the last few years the yuan has appreciated. However, the fact is that by keeping a more or less fixed exchange rate (pegged to the dollar), China is not in control of its monetary policy (it is importing America’s). Related to this point is the view that Chinese savings are needed to finance the U.S. current account imbalance. This is absolutely incorrect, as Chinese dollar savings cannot preexist the U.S. current account deficit. Rather, it is the purchase of imports by Americans - which result from U.S. domestic credit creationthat provides the dollar savings accumulated by the Chinese (Felipe 2009: 266). Indeed, China (and the rest of the world in general) depends on U.S. domestic credit creation to fund its desire to save dollar-denominated U.S. financial assets. From this point of view, the misleadingly called imbalances are simply the result of consumer choices driven by different rates of time preference for consumption and savings, and policies aimed at correcting them are futile and can even be harmful.

\footnotetext{
${ }^{3}$ Paradoxically, as an important part of China's stimulus package focuses on state-directed lending for investment, the country's dependence on investment will remain. It is important that public investment remains strong. As China becomes more market oriented, private investment-led growth will make the financial system increasingly fragile and the country will be more prone to financial crises (Minsky 1973).
} 


\section{DEVELOPING ASIA'S MEDIUM- AND LONG-TERM GROWTH AND DEVELOPMENT PROSPECTS}

As noted earlier, the Asian Development Outlook Update 2009 is optimistic and bets on a V-shaped recovery of the region, led by east and south Asia. Data for the second quarter of 2009 on industrial production and exports indicate that there is light at the end of the tunnel. The key will be to maintain coherent monetary and fiscal policies in the form of easy monetary policy and strong fiscal stimulus. As I argued earlier, it is still premature to relax the stimulus measures and to tighten monetary policy, as this could derail a fragile recovery.

What will happen after this crisis ends and, in particular, what new global financial system emerges as a consequence of the turmoil is anybody's guess. It will all depend on many factors, both political and economic. For example, the 1973-1982 crisis witnessed a process of liberalization that proved successful in reducing labor costs for business. The world also saw important changes in some areas of the third world. China, for example, started opening and became a huge market for developed countries’ products. Today, some fear that this crisis may lead to a process of deglobalization that would have negative consequences for the whole world. Another determining factor will be the changing balance of power between creditor and debtor nations.

Apart from these key underlying and deep socio-political factors, there are economic factors that help us understand the duration of crises and what determines growth in the medium to long term. These factors can be summarized in what is known as "structural change," that is, the process whereby workers shift across sectors and economies learn how to produce and export different (more diversified and sophisticated) baskets of products.

In this vein, recent research by Hausmann et al. (2008) concludes that a measure of a country's export structure (of products), which captures the flexibility of an economy to adapt to external shocks, and encapsulates the potential for further structural change is an important predictor of crisis recovery. This measure, which they call open forest, is a weighted average of the sophistication of all potential export goods of a country (i.e., those goods not yet exported with comparative advantage), where the weight is the density or distance between each of these goods and the economy's present export basket. 
Density (distance) in this context is not a physical concept; rather, it measures how close (far) a commodity not exported with comparative advantage is to the country's export basket. It is a proxy for the probability that a country can successfully export a "new" product (i.e., that it acquires revealed comparative advantage in it). The sophistication of a good is calculated as a weighted average of the incomes per capita of the countries that export the product. ${ }^{4}$

I have calculated open forest for 105 countries using data for 2006. I work with a highly disaggregated data set covering almost 800 products. First, I calculate the number of products in which a country exhibits revealed comparative advantage (i.e., when the share of the product in the country's export basket is greater or equal than the one in the world's basket) out of the 800. Suppose a country has revealed comparative advantage in 200 of the 800 products. These 200 products represent the country's current export basket. Second, I calculate the sophistication of each of the 800 products. Third, I calculate the distance between the current export basket (the 200 products in which the country has revealed comparative advantage) and each of the 600 products not exported with comparative advantage. Fourth, I compute open forest as the sum of the 600 multiplications of density times sophistication. This measure reflects the (expected) value of the goods that the country could potentially export (i.e., the other 600 products that it currently does not export with comparative advantage). This value, therefore, depends on how far the non-exported goods are from the current basket (i.e., distance, or the probability that the country can export them), and on how sophisticated these nonexported goods are. Hausmann el al.'s (2008) analysis indicates that countries with a higher open forest, that is, with a more flexible export basket (in the sense that this allows

${ }^{4}$ Open_Forest $_{c}=\sum_{j}\left[\frac{\sum_{i} \varphi_{i j} x_{c i}}{\sum_{i} \varphi_{i j}}\left(1-x_{c j}\right) P R O D Y_{j}\right]$, where $\omega_{c j}=\frac{\sum_{i} \varphi_{i j} x_{c i}}{\sum_{i} \varphi_{i j}}$ is the density and $x_{c i, c j}=\left\{\begin{array}{l}1 \text { if } \mathrm{RCA}_{i, j} \geq 1 \text { for country } c \\ 0 \text { if } \mathrm{RCA}_{i, j}<1 \text { for country } c\end{array} ; \varphi_{i j}\right.$ denotes the proximity or probability that the country will shift resources into good $j$, given that it exports good $i ; P R O D Y_{j}$ is a measure of the sophistication of product $j$ (not exported with comparative advantage), calculated as a weighted average of the income per capita of the countries that export it; and $\omega_{c j} P R O D Y_{j}$ is the expected value (in terms of the sophistication of exports) of exporting good $j$. 
jumping into other products more easily) are better prepared to react successfully to adverse export shocks.

After calculating open forest for the 105 countries in the analysis, I have estimated the statistical relationship between this variable and income per capita, its square, the investment-output ratio, and the number of export destinations. This is shown in figure 1. It is worth noting that the relationship is quadratic, an inverted U-shaped, indicating that open forest increases up a given level of income per capita (about $\$ 27,000)$ and then it starts declining. Open forest varies significantly across countries. There are countries with a low income per capita, but whose open forest is as high as those of countries in the $\$ 20,000-\$ 40,000$ per capita range. Likewise, large variations in open forest can also be observed within a relatively low range of income per capita (e.g., $\$ 1,000-\$ 5,000)$. 
Figure 1. Opportunities for Economic Transformation: Open Forest

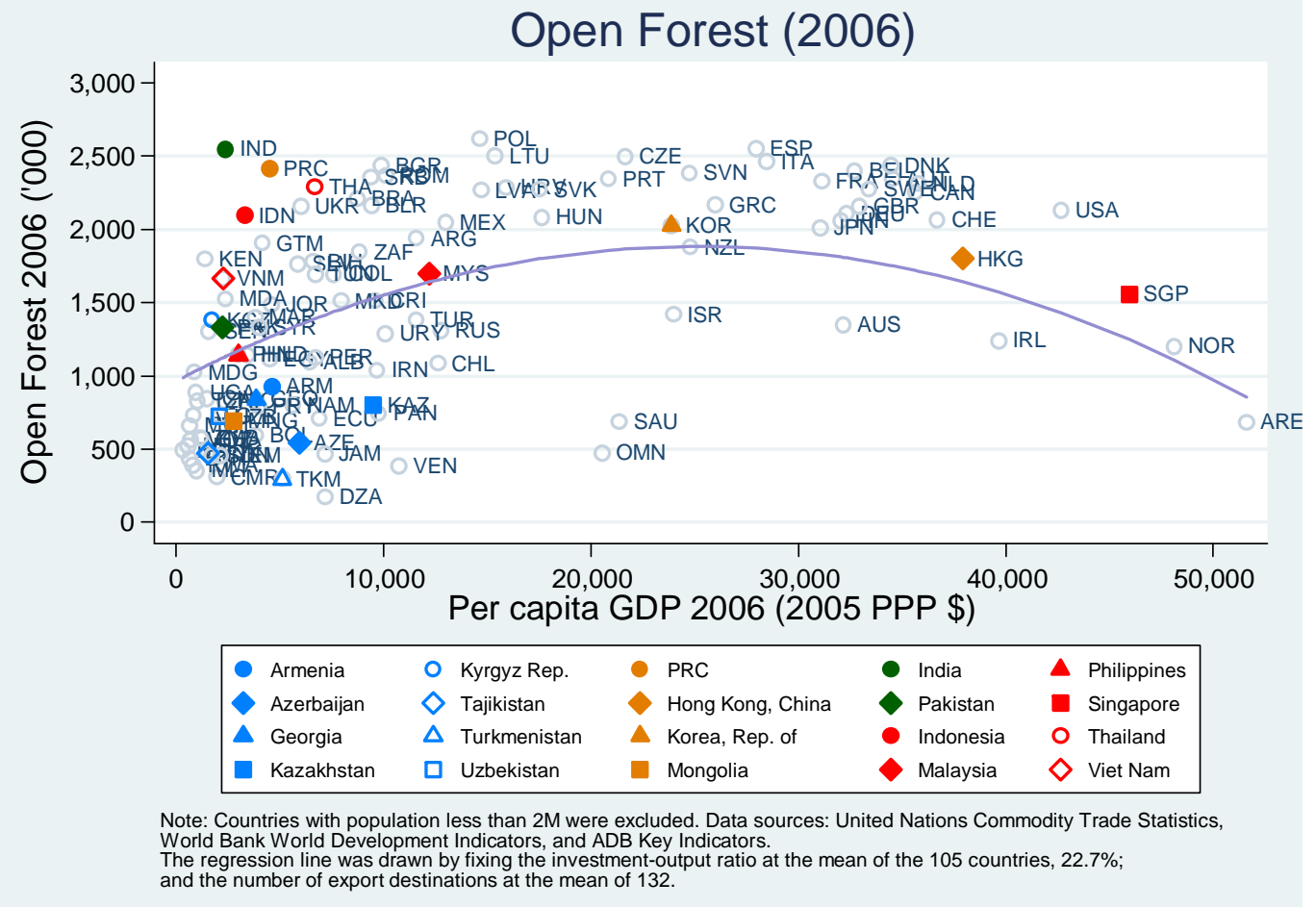

\begin{tabular}{|l|l|l|}
\hline $\begin{array}{l}\text { Countries with actual } \\
\text { open forest higher than } \\
\text { predicted }\end{array}$ & $\begin{array}{l}\text { Countries with actual } \\
\text { open forest lower than } \\
\text { predicted }\end{array}$ & $\begin{array}{l}\text { Countries with similar } \\
\text { actual and predicted open } \\
\text { forest }\end{array}$ \\
\hline Kyrgyz Rep. $(1,379 ; 516)$ & Malaysia $(1,699 ; 1,911)$ & Hong Kong, China $(1,801 ; 1,939)$ \\
\hline India $(2,548 ; 1,716)$ & Armenia $(928 ; 1,204)$ & Singapore $(1,556 ; 1,529)$ \\
\hline Indonesia $(2,096 ; 1,548)$ & Rep. of Korea $(2,025 ; 2,333)$ & Viet Nam $(1,664 ; 1,675)$ \\
\hline Thailand $(2,288 ; 1,858)$ & Mongolia $(693 ; 1,006)$ & Pakistan $(1,331 ; 1,364)$ \\
\hline China $(2,414 ; 2,107)$ & Georgia $(839 ; 1,158)$ & Philippines $(1,143 ; 1,182)$ \\
\hline Tajikistan $(472 ; 238)$ & Kazakhstan $(799 ; 1,313)$ & \\
\hline Uzbekistan $(723 ; 565)$ & Azerbaijan $(543 ; 1,142)$ & \\
\hline & & \\
\hline
\end{tabular}

Source: Author's calculations

Note: The first figure in parenthesis is the value of the actual open forest, while the second is that of the predicted.

Developed countries have, in general, comparative advantage in more products than developing countries, indicating a higher level of export diversification. This may be interpreted to indicate that these countries have lower possibilities for further diversification. However, this is not exactly what matters for purposes of open forest. Developed countries have comparative advantage in sophisticated products (e.g., some types of machinery). These products are "close” to many other sophisticated products (e.g., other types of machinery or chemicals) in the sense that there is a high probability 
that the country can export new products successfully (i.e., that it can acquire comparative advantage) because they use capabilities that are similar to the ones it already possesses. On the other hand, there are products that are "far" from the current basket (i.e., high distance and hence low probability that the country acquires comparative advantage in them) and most likely developed countries will probably not export. These products tend to have low sophistication (e.g., natural resources, some agricultural products) and contribute little to open forest. Therefore, even though developed countries have revealed comparative advantage in the export of a large number of goods (some developed countries in about 300 products out of the almost 800 in the analysis), many of the products that they do not export with comparative advantage are highly sophisticated and the probability of exporting them is high. Hence the relatively high open forest of these countries.

In the case of many developing countries, even though they can potentially export many products (those in which they do not have revealed comparative advantage) and most of them are sophisticated (e.g., machinery), the probability that these countries export them is low because they do not have the capabilities to do it (i.e., they are far from the current export basket). Hence the low open forest of these countries.

The line in figure 1 provides the expected value of open forest given income per capita; to draw it, I fix the investment-output ratio and the number of export destinations at their sample's averages, $22.7 \%$ and 132, respectively. The table below the figure splits the Asian countries into three groups: (i) those whose actual open forest is higher than the one predicted by the regression; (ii) those whose actual open forest is lower than the one predicted by the regression; and (iii) those countries where actual and predicted are about the same. I also show actual and predicted open forest values.

The results show that India and China have very high open forest values, among the highest in the world, and significantly higher than the regression predicts. This is also the case of Indonesia and Thailand. This group also contains three of the ex-Soviet Republics in central Asia: the Kyrgyz Republic, Tajikistan, and Uzbekistan (these three countries have very low open values, especially the last two). This is remarkable given their low income per capita. This analysis provides a powerful explanation for why these countries have been star performers and why, if the right policies continue being implemented, they are poised to have a bright medium- to long-term future. These 
countries implemented an export-led growth model that, among other things, led to the diversification of their export baskets and, in doing so, they gained comparative advantage in exports of relatively sophisticated products that are "close" to other sophisticated manufactures (this is clearly the case of China). They achieved this by developing their industrial capabilities, rather than by specializing according to their static comparative advantages. This is the secret of their success and the lesson for other developing countries: an export orientation focusing on diversification of manufactures and increasing sophistication. ${ }^{5}$

Korea, Malaysia, some of the ex-Soviet Republics of central Asia, and Mongolia have open forest values below the predicted ones. It is difficult to explain why the first two have actual values below the predicted ones (although both of them have high open forest, especially South Korea). Explaining the second group, however, is easier. The reason is to be found in the structure of their actual export basket, dominated by fuels and raw materials. These are relatively unsophisticated products, as they are largely exported by other developing countries. These products require very specific capabilities (e.g., think of oil production) that cannot be easily redeployed for the production and export of other goods. Hence, sophisticated products are far from their current export basket (i.e., the probability of exporting them successfully is low). The result is a low open forest. Countries such as Venezuela, Saudi Arabia, Chile, or Russia, among others (all of them exporters of natural resources) have the same problem. It is obvious that these countries have to diversify their export basket if they want to succeed in the medium to long term.

\section{THE FUTURE OF DEVELOPING ASIA}

In the coming decades, countries across developing Asia will have to pay attention to two key issues (Felipe and Hasan 2006; Felipe 2009). The first is continued structural transformation, that is, the transfer of resources (especially labor) from low-productivity activities, essentially in agriculture, into high-productivity activities in industry and services (i.e., also the more sophisticated activities). This is the key to high and sustained growth. Second, they will have to bring the goal of full employment of the labor force to the top of the policy agenda. Unemployment and underemployment are pervasive across

\footnotetext{
${ }^{5}$ Hausmann et al. (2007) show that that, controlling for initial income level, the initial level of sophistication of the export basket is a good predictor of future growth.
} 
developing Asia and sooner or later this problem will become policymakers’ biggest headache. Felipe and Hasan (2006) estimate the there are about 500 million people unemployed and underemployed in developing Asia. Unemployment has increased in much of the region during the current crisis. In the case of China, and despite the massive stimulus package (and growth in 2009 at slightly over 8\%), the China Development Research Foundation has estimated that over 40 million workers have lost their jobs as a consequence of the crisis.

Many countries in this region of the world have been praised for their exceptionally high growth rates during the last few decades. Structural change has had a lot to do with it. Although in many countries the largest employer continues to be the agricultural sector (including China and India), a significant share of agricultural employment has been transferred to industry and, in particular, services (activities of higher productivity); this, together with an export-led model driven by the emphasis on increasing the sophistication and quality of the export basket, explains, to a significant extent, the region's excellent performance. However, often high growth has not translated into the required job creation (given the number of entrants into the labor force), with the result that unemployment and underemployment have increased. One reason why this has occurred is that structural transformation involves significant reallocation of labor across sectors and it is very difficult to coordinate these shifts in such a way that the workers laid off from one sector find jobs in another one that is expanding. Moreover, often new techniques are highly labor-saving, with the consequence that huge new investments in plant and equipment might require low amounts of labor. In recent years, employment in China has grown by only 1\% per annum despite the high GDP growth, pointing to a low employment elasticity. Felipe and Hasan (2006: 114) estimate that while in the 1980s it took a $3 \%$ growth rate of output to induce 1\% increase in employment, in the 1990 s, China needed to grow by $8 \%$ to generate the same result.

Moreover, for decades, governments and central banks in many developed and developing countries have been more concerned with keeping inflation low at the cost of maintaining relatively high unemployment rates.

For these reasons, while growth is important, it cannot be the ultimate objective of public policy. Policymakers across Asia must implement policies that lead to the full employment of the labor force. An economy running at full employment creates a high 
level of overall purchasing or spending power. This will lead to more buoyant markets, businesses, investment, and employment. Moreover, an economy operating at full employment has the capacity to deliver great individual and social benefits. The economic and social costs of unemployment and underemployment are huge. They not only have economic significant economic costs (e.g., loss of potential output and income, lower tax revenues due to a lower tax base, deterioration of labor skills, and productivity), but also add to poverty, misery, malnutrition, and social injustice. Overall, a full employment economy will provide everyone with opportunities. It is the most direct way to achieving the ultimate objective of economic policy, namely to improve the long-run well-being of all the people in the country, especially the most disadvantaged. 


\section{REFERENCES}

Asian Development Bank (ADB). 2007. Outlook and Outlook Update. Manila, Philippines: Asian Development Bank.

. 2008. Outlook and Outlook Update. Manila, Philippines: Asian Development Bank.

. 2009. Outlook and Outlook Update. Manila, Philippines: Asian Development Bank.

Baumol, W.J., S. Blackman, and E.N. Wolff. 1989. Productivity and American Leadership: The Long View. Cambridge, MA: MIT Press.

Braningin, William. 2009. “A Long, Hard Journey Back to Job Growth in Asia.” In Development Asia. Manila, Philippines: Asian Development Bank.

Felipe, Jesus. 2009. Inclusive Growth, Full Employment and Structural Change: Implications and Policies for Developing Asia. London: Anthem Press.

Felipe, Jesus, and Rana Hasan (eds.). 2006. Labor Markets in Asia: Issues and Perspectives. London: Palgrave Macmillan.

Felipe, Jesus, Editha Laviña, and Emma Xiaoqin Fan. 2008. "The Diverging Patterns of Profitability, Investment and Growth of China and India, 1980-2003.” World Development 36(5): 741-774.

Felipe, Jesus, Norio Usui, and Arnelyn Abdon. 2010. "Why has China succeeded? And why it will continue to do so. A look into the product space.” Mimeograph. Manila, Philippines: Asian Development Bank.

Gupta, Souvik, and Jacques Miniane. 2009. "Recessions and Recoveries in Asia: What can the past teach us about the present recession?” Working Paper No. 150. Tokyo: Asian Development Banks Institute.

Hausmann, Ricardo, Jason Hwang, and Dani Rodrik. 2007. "What you export matters." Journal of Economic Growth 12(1): 1-15.

Hausmann, Ricardo, Francisco Rodriguez, and Rodrigo Wagner. 2008. "Growth Collapses.” in Carmen M. Reinhart, Carlos A. Vegh, and Andres Velasco (eds.), Money, Crises and Transition. Cambridge, MA: The MIT Press.

International Labour Organization (ILO). 2009. World of Work Report 2009. International Labour Organization.

International Monetary Fund (IMF). 2009. World Economic Outlook. April and September. Washington, DC: International Monetary Fund. 
Minsky, Hyman. 1973. “The Strategy of Economic Policy and Income Distribution.” The Annals of the American Academy of Political and Social Science, 409(September): 92-101.

Park, Donghyun, and Kwanho Shin. 2009. "Can Trade with the People’s Republic of China be an engine of growth for developing Asia?” Working Paper Series, No.172, October. Manila, Philippines: Asian Development Bank.

Reinhart, Carmen M., and Kenneth S. Rogoff. 2009. “The Aftermath of the Financial Crises.” Working Paper No.14656. Cambridge, MA: National Bureau of Economic Research (NBER).

Rodrik, Dani. 29009. “Growth after the crisis.” (May 12, 2009 version). Cambridge, MA: Kennedy School, Harvard University. 